Our Nature 2013, 11(1): 1-10

\title{
Investigation on Species Composition of Plant Community at Tad Xai at Phou Khao Khouay National Park, Lao PDR
}

\author{
Metmany Soukhavong ${ }^{1 *}$, Liu Yong ${ }^{1}$, Khamseng Nanthavong $^{2}$ and Jérôme Millet ${ }^{3}$ \\ ${ }^{1}$ College of Forestry, Beijing Forestry University, China \\ ${ }^{2}$ Faculty of Forestry, National University of Lao PDR \\ ${ }^{3}$ Fédération des Conservatoires botaniques nationaux Montreuil-sous-Bois France \\ "E-mail: metmany_heen@yahoo.com
}

Received: 19.04.2013, Accepted: 11.05.2013

\begin{abstract}
Phou Khao Khouay (PKK) National Park is one of the 21 National Parks in Lao PDR that supports high biodiversity. The plant community was represented by 62 families, 145 species and 1,221 tree size individuals in $50 \times 50 \mathrm{~m}^{2}$ plots. The largest species in terms of individual number were Hydnocarpus ilicifolia, Hopea spp. and the largest families in terms of species number were Rubiaceae and Dipterocarpaceae. A total 24 families, 33 species and 91 sapling individuals were found in the $10 \times 10 \mathrm{~m}^{2}$ sapling plots, the largest species were Rinorea boissieui, Ailanthus triphysa and Hopea spp. and the largest families were Dipterocarpaceae and Myrtaceae. In the seedling quadrat, there were 88 families, 153 species and 1,586 seedling size individuals in $2 \times 2 \mathrm{~m}^{2}$ plots, the largest species were Hopea spp., Hopea ferrea and spp. (leguminoceae), the largest families were Rubiaceae, Annonaceae and Dipterocarpaceae. Diversity was found very high in tree and seedling was significantly higher than that of sapling, but no significant difference between tree and seedling. The largest tree height and maximum mean diameter at breast height (DBH) belonged to the family of Dipterocarpaceae. Canopy cover of Diperocarpaceae was highest (35\%) in study area. Lauraceae and other 6 families had lowest crown cover around 5\%. The result of this study indicated the pattern of species composition in plant community assembly and density, diversity, abundance for the vegetation layers.
\end{abstract}

Key words: Diversity, Species composition, Plant community, Diversity index, Phou khao khouay, Laos

\section{Introduction}

Tropical rainforests cover approximately $60 \%$ of the region's total forest area; with tropical moist deciduous forests and tropical dry forests each accounting for around 15\% and mountain forests another 10\% (FAO, 2001). Tropical rain forests are the most productive and biologically diverse terrestrial ecosystems (Leigh, 1999). They cover less than $<10 \%$ of the Earth's land surface yet contain close to half of all species. A fundamental question for ecologists concerns mechanisms of species coexistence, particularly at small spatial scales in diverse forests (Wright, 2002). The plant community ecologists are concerned with patterns of species response to environmental gradients (Moore and Keddy, 1989; Wisheu and Keddy, 1989) and tend to 
Metmany Soukhavong, Liu Yong, Khamseng Nanthavong and Jérôme Millet

/ Our Nature (2013), 11(1): 1-10

adopt (if only implicitly) a continuum approach to vegetation with its assumption of continuous change in composition with position in the multi-dimensional environmental space (Austin, 1985; 1999). Huston $(1979,1994)$ reviewed species richness extensively, and regarded patterns of species richness as being determined by the interaction of disturbance with environmental gradients and competitive exclusion. Plant community composition both affects and is affected by ecosystem structure and function. For example, species composition and diversity strongly influence ecosystem processes, such as nutrient cycling, productivity, decomposition rate, and trophic dynamics, particularly if the traits of one or a few species have strong ecosystem effects (Hooper and Vitousek, 1997). Plant diversity is important because various species come to depend on each other; so, eliminating one species can cause several other species to suffer. The debate over the concept of diversity and its measurement is not new. McMinn (1991) makes a distinction between biodiversity and diversity. The concept of diversity is well represented in linguistics, social, and physical sciences (Patil and Taillie, 1982). However, as Pielou (1975) pointed out, complexity of a community's plant species composition does not reflect the diversity of other classification levels. This study was carried out to study the pattern of species composition in plant community assembly and the density, diversity, abundance for the vegetation layers to provide information and guideline for forest management in a sustainable basis.

\section{Materials and methods Study site}

PKK national park (Long. $18^{\circ} 14^{\prime}-18^{\circ} 32^{\prime} \mathrm{N}$, Lat. $\left.102^{\circ} 38^{\prime}-102^{\circ} 59^{\prime} \mathrm{E}\right)$ is one of the 21 protected areas of Lao PDR which was under the Ministry of Defense in 1994. Now the aims of management are to restore, enhance the biodiversity, and maintain habitat and ecosystem value of the park. It is rich in diversity as there are many species of plants constituting dense forest. It is located $40 \mathrm{~km}$ northeast from Vientiane province at it closest point, it covers three provinces as: Vientiane province, Vientiane Prefecture and Borlikhamxay province.

The monsoonal climate is similar to the rest of central Lao PDR, the rainy season is from May to October and a distinct dry season from November to April. Average annual rainfall is $2,202.4 \mathrm{~mm}$ with $92 \%$ of this rainfall in rainy season. The temperatures are highest just before and during the early part of the rainy season, and the April is the hottest month with temperature average $39^{\circ} \mathrm{C}$. December is the coldest month with average $10^{\circ} \mathrm{C}$ at the low elevation (Lao Metrology Department, 2011).

Topology is generally steep sloping in the low elevation central portion of the area and on the PKK plateau. Elevation varies from less than $100 \mathrm{~m}$ to nearly $1,700 \mathrm{~m}$ above mean sea level. Most of the area is over $500 \mathrm{~m}$ and a large part is above 1,000 $\mathrm{m}$. PKK is found on rough mountain slopes, steep sandstone cliffs, hilly terrains or flat uplands. This steep topography characterizing the area has been shaped by the uplifting and exposure of the underlying sediments (Indosinias schist-clay-sandstone) (Salter and Phanthavong, 1990). There are also extensive flat uplands of exposed sandstones with little or no soil development. The mountain range of PKK 
Metmany Soukhavong, Liu Yong, Khamseng Nanthavong and Jérôme Millet

/ Our Nature (2013), 11(1): 1-10

is formerly layered sandstone which is still visible as linear outcrops or on large boulders. Most of the area is covered by poor soil. Richer soils (dystric nitosols, ferratic cambisols) is found in valleys and river gorges where the moisture level is high so these soils support the richest forests called evergreen forest with emergent trees up to $40 \mathrm{~m}$ in height. Most of the area is considered to be poorly suited for cultivated crops due to topography and soil limitations. Empirical evidence suggests that climate, topography and geology combine to make most of the sloping land susceptible to erosion and more suited to production of trees than to arable crops (Aman, 2001).

Within study area at Tad Xai in the PKK National Park, averages $\mathrm{pH}$ of $\mathrm{H}_{2} \mathrm{O}$ was $4.75, \mathrm{KCl}$ of soil was $4.19 \%$, organic matter in the soil such as nitrogen was $0.09 \%$, phosphorus $\left(\mathrm{P}_{2} \mathrm{O}_{5}\right) 0.004 \%, \mathrm{~K}_{2} \mathrm{O}$ $0.02 \%$ and particle size such as sand was $58.58 \%$, clay $16.34 \%$ and silt $24.46 \%$.

\section{Sampling plot and procedure}

This study followed permanent forest plot quadrat with $50 \times 50 \mathrm{~m}^{2}$, established in different area of PKK national park in 2009 by the Institute Rcherche pour le Development (IRD), France and Faculty of Forestry (FOF), National University of Laos. The IRD-FOF project established some pilot plots in PKK protected area in Laos which was intensively logged before for road to villages which threatened the forest biodiversity. The project was 32 plots established in this protected area among them 15 plots were in the Vang Heua village (Vientiane province), 11 plots in the Tad Xai, Hard Khai village (Borlikhamay province) and 6 plots in the Tad Leuk (Borlikhamxay province). The IRD-FOF project was carried out for the estimation of forest composition and detailed information about trees, soil and forest habitat but not on the sapling and seedling in the plot. We selected one part of the IRD-FOF project at the Tad Xai as our study area, there were 11 permanent plots (Fig. 1) and the investigation was carried out on species composition of plant community including trees, sampling and seedling in the plot.

\section{Method and sample plot design}

The sampling plots established in the forest area, covered the physical features of the forest and plant species availability. Sampling plots were a hierarchy subplot for different measurements recognizing the efficiency of scaling plot site and number to the vegetation stratum meant to describe (Greig-Smith, 1983; Elzinga et al., 1998). Sampling plot $10 \times 10 \mathrm{~m}^{2}$ was centered at the plot $50 \times 50 \mathrm{~m}^{2}$ and $2 \times 2 \mathrm{~m}^{2}$ subplots were established in four corners of the largest plot $50 \times 50 \mathrm{~m}^{2}$.

1. The largest sampling plot $50 \times 50 \mathrm{~m}^{2}$ was designed by taking $50 \mathrm{~m}$ each north then east, south and west in clockwise direction from the base tree which was considered as the reference point. It was purposed to collect the information about the trees and woody climbers found within this sampling plot. The collected indices were species name, $\mathrm{DBH}$, height and canopy width for the tree $\mathrm{DBH}>10 \mathrm{~cm}$.

2. The second sampling plot $10 \times 10 \mathrm{~m}^{2}$ was positioned at the center of the largest quadrat by taking $10 \mathrm{~m}$ each north then east, south and west in clockwise direction. This quadrat was used to collect the information on shrubs, saplings and herbaceous climbers 
Metmany Soukhavong, Liu Yong, Khamseng Nanthavong and Jérôme Millet

/ Our Nature (2013), 11(1): 1-10

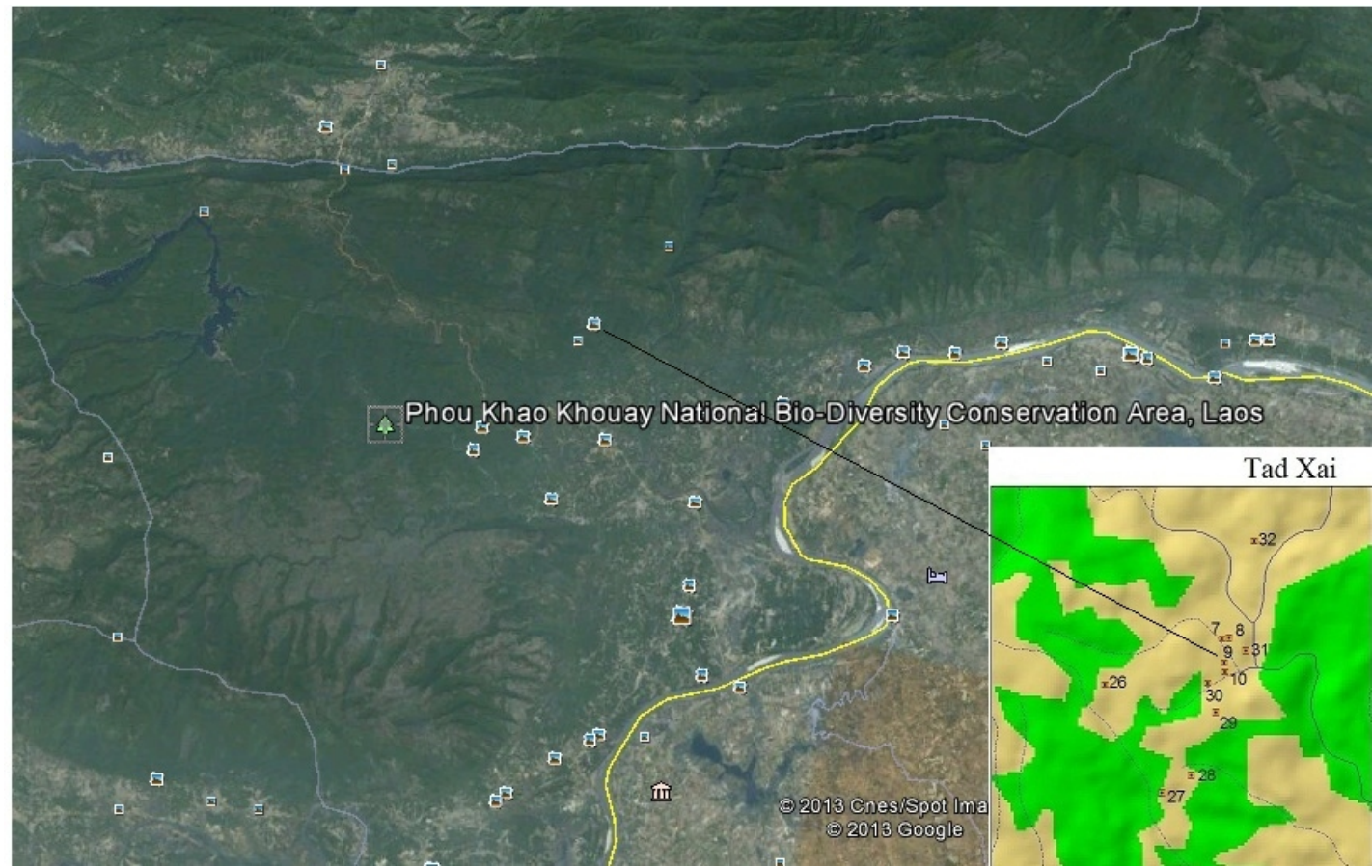

Figure 1. Sample plot at Tad Xai in the PKK National Park.

and encountered. The collected indices were species name, $\mathrm{DBH}$ and height for the sapling $\mathrm{DBH}>5 \sim<10 \mathrm{~cm}$.

3. The smallest sample plot $2 \times 2 \mathrm{~m}^{2}$ was used to collect the information on seedlings. The collected indices were species name, $\mathrm{DBH}$ and height for the seedling $\mathrm{DBH}<5$ and height not more than $130 \mathrm{~cm}$.

\section{Data analysis}

Data analysis was carried out following Curtis and Cottam (1962) and density (D), abundance (A), frequency (F), relative density (RD), relative abundance (RA), relative frequency (RF) and importance value index (IVI) was calculated for each species.

\section{Results and discussion Tree layer}

A total of 145 species and 1,221 individuals in the tree layer, belonging to 62 families were recorded. Among families, Rubiaceae (9 species), Myrtaceae and Lauraceae were presented by 8 species each, Dipterocarpaceae and Ebenaceae by 7 species each, Moraceae, Leguminosae-Papilionoideae and Meliaceae by 6 species each, Euphorbiaceae (5 species), Lythraceae and Polygalaceae by 4 species each, Annonaceae,Sapindaceae, Melastomataceae,Leguminosae, Caesalpinioideae, Malvaceae, Burseraceae, Clusiaceae and Sterculiaceae by 3 species each. Eight families had two species each and remaining 35 families had single species. The number of tree species (145) recorded 
Metmany Soukhavong, Liu Yong, Khamseng Nanthavong and Jérôme Millet

/ Our Nature (2013), 11(1): 1-10

in the present study was found to be higher than the number of species reported by several studies in the different tropical forests viz., 85 species (Chowdhury et al., 2000), 94 species (Fox et al., 1997), 123 species (Supriya devi and Yadava, 2006), 52 species (Pande, 1999), 87 species (Uma Shanker, 2001) and tropical seasonal rainforest in Xishuangbanna viz., 84-106 species (Lü et al., 2010), relatively similar to mature tropical forest from South-East Asia viz., 62-247 species (Losos et al., 2004) and greater than tropical seasonal rainforest in Philippine viz., 92 species (Hamann et al., 1999) and lower than the value viz., 148 species (Mekail et al., 1997) in different forest type.

Dipterocarpaceae with 215 individuals ranked first in term of individual density followed by Achariaceae, Myrtaceae, Lauraceae and Rubiaceae. The Dipterocarpaceae family is top abundant family in the tropical rainforest of South-East Asia (Proctor et al., 1983; Hamann et al., 1999; Small et al., 2004; Kessler et al., 2005). However, the most dominant families observed in this study were Rubiaceae, Myrtaceae and Lauraceae the same result was observed in Xishuangbanna, South-West, China (Lü et $a l ., 2010)$ and forest in Vietnam (Blanc et al., 2000).

\section{Sapling layer}

In the sapling layer, a total of 33 species and 91 individual belonging to 24 families were recorded. Among families, Dipterocarpaceae was represented by 4 species, Myrtaceae by 3 species, and Moraceae, Melastomataceae, Sapindaceae and Simaroubaceae by 2 species each. Eighteen families had single species.

\section{Seedling layer}

A total of 153 species and 1,586 individuals belonging to 88 families were recorded. Among families, Rubiaceae was represented by 14 species, Annonaceae, Dipterocarpaceae, Meliaceae, and Moraceae by 5 species each, Apocynaceae, Euphorbiaceae, Leguminosae, Caesalpinioideae, Leguminosae, Papilionatae, Myrtaceae and Sterculiaceae by 4 species each, and Guttiferae, Melastomataceae and Sapindaceae by 3 species each. Twelve families had two species each and remaining 62 families had single species.

\section{Species composition}

Tree layer of the top five species, Hydnocarpus ilicifolia exhibited maximum density (174 individuals) followed by Hopea sp (118 individuals), Hopea ferrea (74 individuals), Lagerstroemia calyculata and Alphonsea gaudichaudiana (44 individuals). Considering IVI as an indicator of dominance Hydnocarpus ilicifolia dominated tree layer. The result showed that species dominance in tree layer was different from that in sapling and seedling layer. Hopea spp. was co-dominant species in the tree layer and was dominant one in the seedling layer. The number of tree species of this study was in the range of tropical seasonal rainforest in Xishuangbanna (84-106 species, Lü et al., 2010), relatively similar to mature tropical forest from South-East Asia (62-247 species, Losos et al., 2004) and greater than tropical seasonal rainforest in Philippine (92 species, Hanman et al., 1999).

Sapling layer of the top five species were recorded, of which highest density was 9 individuals of Rinorea boissieui followed 
Metmany Soukhavong, Liu Yong, Khamseng Nanthavong and Jérôme Millet

/ Our Nature (2013), 11(1): 1-10

by Ailanthus triphysa (7 individuals), Hopea sp (7 individuals), Shorea roxburghii (6 individuals) and Hydnocarpus ilicifolia (5 individual). Considering IVI as an indicator of dominance Rinorea boissieui dominated sapling layer. The results showed that dominant species of this layer was Rinorea boissieui, Ailanthus triphysa (Dennstedt) Alston and Hopea spp. In sapling layer, the species was not the same as in tree and seedling layer, this may be due to differences in natural condition. Odum's (1971) clump distribution was the most common type distribution that is caused by small but significant variation in the environmental conditions.

Seedling layer of the top five species revealed that Hopea $s p$. had highest density (147 individuals) followed by Hopea ferrea (85 individuals), Alpinia spp., Terminalia catappa (70 individuals each) and Eurycoma longifolia (54 individuals). Considering IVI as an indicator of dominance Hopea sp. dominated seedling layer. The dominance of the seedling in any species can be considered as the regeneration potential of that species in the forest. Dominant species in this area was Hopea spp. but in the community it was codominant in the tree layer. Moreover, comparing with species between tree and seedling layer one could infer that the forest is moving toward more diverse composition of species (Tab. 1).

Table 1. Top five importance value index (IVI) and density of difference species at difference layer of the study site.

\begin{tabular}{lcc}
\hline Name of the species & density & IVI \\
\hline Tree layer & & \\
Hydnocarpus ilicifolia & 174 & 21.61 \\
Hopea sp & 118 & 16.51 \\
Hopea ferrea & 74 & 10.99 \\
\hline
\end{tabular}

\begin{tabular}{lcc}
\hline Lagerstroemia calyculata & 44 & 7.38 \\
Alphonsea gaudichaudiana & 44 & 7.23 \\
\hline Sapling layer & & \\
Rinorea boissieui & 9 & 21.13 \\
Ailanthus triphysa & 7 & 18.44 \\
Hopea sp & 7 & 18.44 \\
Shorea roxburghii & 6 & 16.70 \\
Hydnocarpus ilicifolia & 5 & 15.94 \\
\hline Seedling layer & & \\
Hopea sp. & 147 & 14.62 \\
Hopea ferrea & 85 & 10.60 \\
Alpinia spp & 70 & 8.05 \\
Terminalia catappa & 70 & 8.02 \\
Eurycoma longifolia & 54 & 8.02 \\
\hline
\end{tabular}

\section{Species diversity, evenness and richness}

The species diversity $(\overline{\mathrm{H}})$ of difference layer of the study site showed (Fig. 2) that there was a significant difference among tree, sapling and seedling $(P<0.01)$. The highest was recorded for seedling layer (2.83) and followed by tree (2.63) and sapling (1.43).

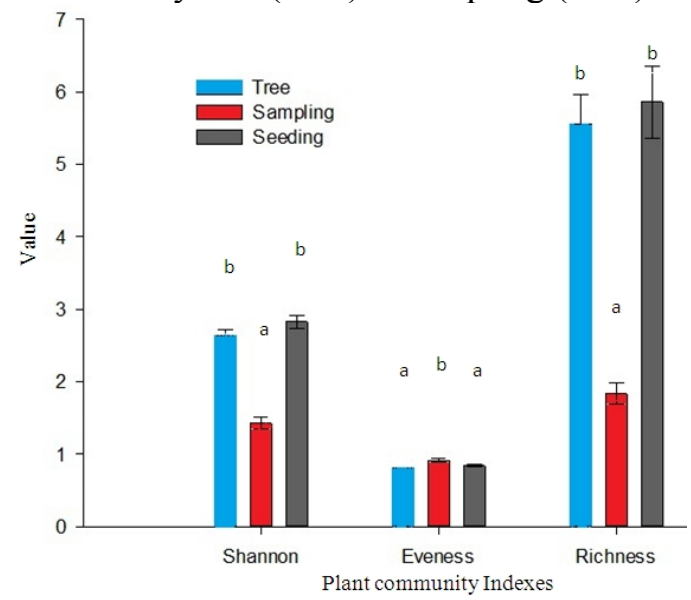

Figure 2. Species diversity, evenness and richness index of plant communities ( $a, b=$ significant difference at 0.05 level).

The species evenness (E) was found different among the sapling and seedling $(P<0.01)$. Sapling was significantly higher than tree and seedling, and no significant difference between tree and seedling. 
Species evenness of sapling was the highest 0.91 followed by seedling $(0.86)$ and tree (0.81).

The species richness $\left(R_{1}\right)$ of different layers was significantly higher than that of sapling, and no significant difference between tree and seedling $(P<0.01)$. This rule is similar to the diversity; the highest was recorded for seedling (5.86) followed by tree (5.55) and sapling (1.84).

\section{Forest structure}

The highest tree at the Tad Xai in PKK protected area belonged to the family of Dipterocarpaceae with the mean height of $17.24 \mathrm{~m}$, it was followed by Polygalaceae with average height $14.7 \mathrm{~m}$ and Cannabaceae with average height $14.68 \mathrm{~m}$. The mean DBH of Dipterocarpaceae was 33.57 $\mathrm{cm}$ which was the maximum; it was followed by Myrtaceae with average DBH of $28.77 \mathrm{~cm}$ and Polygalaceae with average DBH of $28.65 \mathrm{~cm}$. The mean canopy width of Dipterocarpaceae with average $6.68 \mathrm{~m}$ from north to south and $6.70 \mathrm{~m}$ from east to west was maximum width of canopy, it was followed by Cannabaceae with average 6.53 $\mathrm{m}$ from north to south and $6.77 \mathrm{~m}$ from east to west, Myrtaceae with average $6.49 \mathrm{~m}$ from north to south and 6.51 from east to west (Tab. 2)

According to diameter class distribution the forest was uneven aged forest (Fig. 3). The increase in DBH class was associated with decrease in number of individual. Diameter class distribution curve was inverted $j$ shaped that ensures sustained future of the forest if properly managed but also that can be attributed to the unplanned and unsustainable exploitation of woody species in the forest (Alelign et al., 2007). Number of individuals of DBH more than
$50 \mathrm{~cm}$ appeared high due to inclusion of trees up to more than $100 \mathrm{~cm}$ class (Fig 3).

Like other analysis canopy width percentage of Diperocarpaceae was highest (35\%) followed by co-dominant families Achariaceae and Myrtaceae having approximately $15 \%$. Melastomataceae had the lowest crown cover. Lauraceae and other six families had crown cover percent around 5\% (Fig. 4).

\section{Conclusions}

The results of this study indicated that there were 62 families, 145 species and 1,221 individuals in tree plots. The largest species in terms of individual number was Hydnocarpus ilicifolia, importance value index was 21.61 and the largest families in terms of species number was Rubiaceae. There were 24 families, 33 species and 91 individuals in the sapling plots, the largest species was Rinorea boissieui, importance value index was 21.13 and the largest families was Dipterocarpaceae. In the seedling quadrat there were 88 families, 153 species and 1,586 individuals, the largest species was Hopea spp., importance value index was 14.62 and the largest family was Rubiaceae. Diversity was higher in the tree and seedling levels than that in sapling level. The diversity index in the tree, seedling and sapling level was 2.63, 2.83 and 1.43, respectively. The highest tree belonged to the family of Dipterocarpaceae with the mean height of $17.24 \mathrm{~m}$ and the maximum mean DBH of Dipterocarpaceae was 33.57 $\mathrm{cm}$. Canopy cover of Diperocarpaceae was the highest $(35 \%)$ in study area. Lauraceae and other six families had lowest crown cover around $5 \%$.

In brief, there is no estimate or measurement of the volume or productivity 
Metmany Soukhavong, Liu Yong, Khamseng Nanthavong and Jérôme Millet

/ Our Nature (2013), 11(1): 1-10

Table 2. Growth parameters of top families (individual $\geq 20$ ) at the Tad Xai in the PKK Protected Area.

\begin{tabular}{lcccccc}
\hline Family & Individual & \multirow{2}{*}{$\begin{array}{c}\text { DBH } \\
(\mathbf{c m})\end{array}$} & $\begin{array}{c}\text { Height } \\
(\mathbf{m})\end{array}$ & \multirow{2}{*}{ Volume $\left(\mathbf{m}^{\mathbf{3}}\right)$} & \multicolumn{2}{c}{ Canopy } \\
\cline { 5 - 7 } & & 33.57 & 17.24 & 2.58 & 6.68 & 6.70 \\
\hline Dipterocarpaceae & 215 & 21 & 10.61 & 0.38 & 4.88 & 4.94 \\
Achariaceae & 174 & 28.77 & 14.10 & 1.59 & 6.49 & 6.51 \\
Myrtaceae & 97 & 18.22 & 10.45 & 0.29 & 5.12 & 4.84 \\
Lauraceae & 69 & 17.88 & 10.28 & 0.25 & 4.75 & 4.38 \\
Rubiaceae & 68 & 14.76 & 9.79 & 0.17 & 4.14 & 3.75 \\
Lythraceae & 57 & 28.65 & 14.75 & 1.71 & 6.16 & 6.06 \\
Polygalaceae & 53 & 15.21 & 9.37 & 0.16 & 4.78 & 4.84 \\
Annonaceae & 51 & 22.79 & 12.26 & 0.98 & 5.36 & 5.74 \\
Sapindaceae & 50 & 16.66 & 9.27 & 0.24 & 3.95 & 3.93 \\
Ebenaceae & 41 & 15.47 & 8.24 & 0.19 & 4.08 & 3.91 \\
Celastraceae & 34 & 26.75 & 14.68 & 1.08 & 6.53 & 6.77 \\
Cannabaceae & 28 & 15.35 & 9.33 & 0.21 & 4.36 & 4.73 \\
Moraceae & 27 & 15.80 & 8 & 0.15 & 4.44 & 4.17 \\
Melastomataceae & 20 & &
\end{tabular}

$\left(\mathrm{NS}^{*}=\right.$ Measuring canopy from north to south, $\mathrm{EW}^{*}=$ Measuring canopy from east to west)

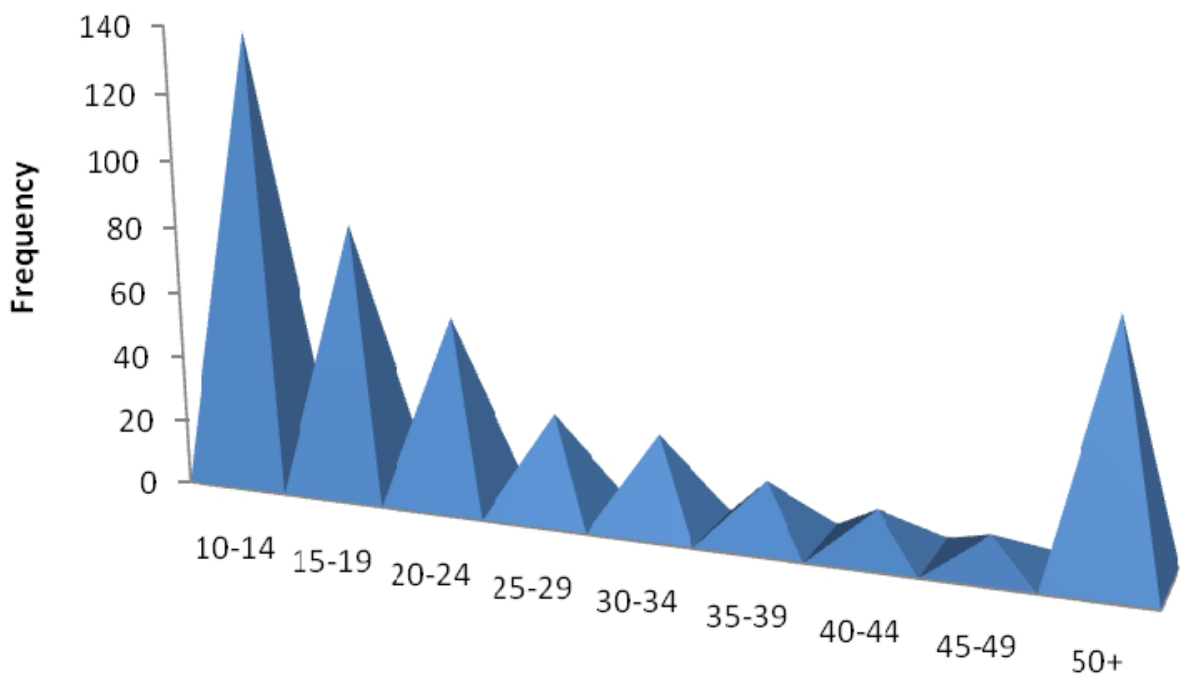

DBH class

Figure 3. Mean DBH of tree individuals. 
Metmany Soukhavong, Liu Yong, Khamseng Nanthavong and Jérôme Millet

/ Our Nature (2013), 11(1): 1-10

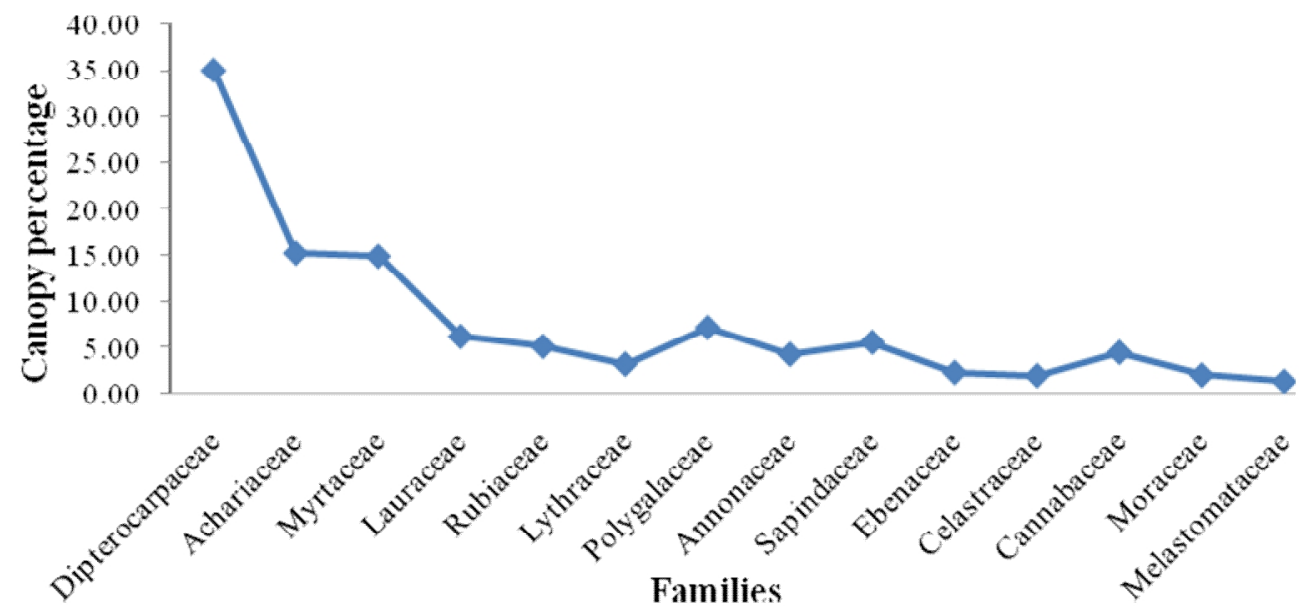

Figure 4. Percentage canopy of different tree families.

of a species in the sample plots thus, in the absence of any data concerning the amount of bare ground, the Index is purely a measure of the contribution of a species to that vegetation which is present, regardless of whether the ground is completely covered or very sparsely covered. Therefore further study of productivity along with IVI is recommended. The result of species composition of the plant community of this study is just based on single forests in one region of the PKK national park; similar comparative study of different geographic regions could be of further interest of study.

\section{References}

Alelign, A., D. Teketay, Y. Yemshaw and S. Edwards 2007. Diversity and status of regeneration of woody plants on the peninsula of Zegie, northwestern Ethiopia. Tropical Ecology 48(1): 37-49.

Aman, 2001. State of environment report 2001: Lao PDR. UNEP/RRC.AP. Retrieved from http://www. ekh.unep.org/?q=node $/ 287$
Austin, M.P. 1985. Continuum concept, ordination methods and niche theory. Annual Review of Ecology and Systematics 16(1): 39-61.

Austin, M.P. 1999. The potential contribution of vegetation ecology to biodiversity research. Ecography 22(5): 465-484.

Blanc, L., G. Maury-Lechon, J.-P. Pascal 2000. Structure, floristic composition and natural regeneration in the forests of Cat Tien National Park, Vietnam: An analysis of the successional trends. Journal of Biogeography 27(1): 141-157.

Chowdhury, M.A.M., M.K. Auda and A.S.M.T. Iseam 2000. Phytodiversity of Dipterocarpus turbinatus Gaertn. F. (Garjan) undergrowths at Dulahazara garjan forest, Cos'B Bazar, Bangaladesh. Indian forester 126: 674-684.

Curtis, J.T. and G. Cottam 1962. Plant Ecology Workbook. Burgess publish.Co.Minneapolis, USA.

Elzinga, C.L., D.W. Salzer and J.W. Willoughby 1998. Measuring and monitoring plant populations. U.S. Dept of the Interior, Bureau of Land Management, National Applied Resource Sciences Center in Denver, Colo.

FAO. 2001. International Action in the Management of Forest Genetic Resources: status and challenges. Paper prepared by Christel PalmbergLerche, September 2000. Forest Genetic Resources Working Papers, Working Paper 


\section{Metmany Soukhavong, Liu Yong, Khamseng Nanthavong and Jérôme Millet / Our Nature (2013), 11(1): 1-10}

FGR/1. Forest Resources Development Service, Forest Resources Division. FAO of the United Nations, Rome, Italy. (unpublished).

Fox, B.J., J.E. Taylor, M.D. Fox and C. Williams 1997. Vegetation changes across edges of rainforest remnants. Biological Conservation 82: $1-13$.

Greig-Smith, P. 1983. Quantitative Plant Ecology, $3^{\text {rd }}$ Edn. Blackwell Scientific, London.

Hamann, A., E.B. Barbon, E. Curio and D.A. Madulid 1999. A botanical inventory of a submontane tropical rainforest on Negros Island, Philippines. Biodiversity and Conservation 8(8): 1017-1031.

Hooper, D.U. and P.M. Vitousek 1997. The effects of plant composition and diversity on ecosystem processes. Science 277: 1302-1305.

Huston, M. 1979. A general hypothesis of species diversity. The American Naturalist 113(1): 81-101.

Huston, M.A. 1994. Biological diversity: The coexistence of species on changing landscapes. Cambridge University Press, Cambridge.

Kessler, M., P.J.A. Kessler, S.R. Gradstein, K. Bach, M. Schmull and R. Pitopang 2005. Tree diversity in primary forest and different land use systems in central Sulawesi, Indonesia. Biodiversity and Conservation 14: 547-560.

Lao Metrology Department 2011. Information report of metrology department of Lao PDR. Retrieved from http://www.monre.gov.la/wrea/

Leigh, E.G. 1999. Tropical Forest Ecology: A view from Barro Colorado Island. Oxford Univ. Press, Oxford and New York.

Losos, E.C., J. Leigh and G. Egbert 2004. The growth of a tree plot network. In: Tropical Forest Diversity and Dynamism: Findings from a LargeScale Plot Network (Eds. E.C. Losos, J. Leigh and E. Giles). University of Chicago Press, Chicago. pp. 3-7.

Lü, X.T., J.X. Yin and J.W. Tang 2010. Structure, tree species diversity and composition of tropical seasonal rainforests in Xishuangbanna, SouthWest China. Journal of Tropical Forest Science 22(3): 260-270.

McMinn, J.W. 1991. Biological diversity research: An analysis. USDA For. Ser. Gen. Tech. Rep. SE$71, \mathrm{pp} 7$.

Mekail, O., S. Lars, H. Greger, Z. Olle and H. Janolof 1997. Habitat qualities versus long-term continuity as determinants of biodiversity in boreal old-growth swamp forests. Biological Conservation 81: 221-231.

Moore, D.R.J. and P.A. Keddy 1989. The relationship between species richness and standing crop in wetlands: the importance of scale. Vegetation 79: 99-106.

Odum, E.P. 1971. Fundamental of Ecology, $3^{\text {rd }}$ Edn. W.B. Saunders Co., Philadelpia, U.S.A. 574p.

Pande, P.K. 1999. Comparative vegetation analysis and sal (Shorea robusta) regeneration in relation to their disturbance magnitude in some sal forests. Tropical Ecology 40: 51-61.

Patil, G.P. and C. Taillie 1982. Diversity as a concept and its measurement. J. Am. Stat. Assoc. 77: 548567.

Pielou, E.C. 1975. Ecological diversity. John Wiley and Sons, New York. 165p.

Proctor, J., J.M. An Derson, P. Chai and H.W. Vallack 1983. Ecological studies in four contrasting lowland rainforests in Gunung Mulu National Park, Sarawak. I. Forest environment, structure and floristic. Journal of Ecology 71: 237-260

Salter, R.E. and B. Phanthavong 1990. Phou Khao Khouay protected area. Management plan. Forest Resource Conservation Project Lao/Swedish Forestry Cooperation Programme.

Small, A., T.G. Martin, R.L. Kitching and K.M Wong 2004. Contribution of tree species to the biodiversity of a 1 ha Old World rainforest in Brunei, Borneo. Biodiversity and conservation 13: 2067-2088.

Supriya Devi, L. and P.S. Yadava 2006. Floristic diversity assessment and vegetation analysis or tropical semievergreen forest of Manipur, North East India. Tropical Ecology 47(1): 89-98.

Uma Shanker, 2001. A case of high tree diversity in sal (Shorea robusta) dominant lowland forest of eastern Himalaya: Floristic composition, regeneration and conservation. Current Science 81: 776-786.

Wisheu, I.C. and P.A. Keddy 1989. Species richnessstanding crop relationship along four lakeshore gradients: constraints on the general model Canadian Journal of Botany 67: 1609-1617.

Wright, S.J. 2002. Plant diversity in tropical forests: a review of mechanisms of species coexistence. Oecologia 130: 1-14. 